\title{
Effects of Tax Reforms on Buoyancy and Elasticity of the Tax System in Kenya: 1963-2010
}

\author{
Ochieng V. Omondi ${ }^{1}$, Nelson H. W. Wawire ${ }^{1}$, Emmanuel O. Manyasa ${ }^{1}$ \& Gideon KiguruThuku ${ }^{2}$ \\ ${ }^{1}$ School of Economics, Kenyatta University, Nairobi, Kenya \\ ${ }^{2}$ School of Business, Karatina University, Kenya \\ Correspondence: Ochieng V. Omondi, School of Economics, Kenyatta University, P. O. Box 1632-00200, \\ Nairobi, Kenya. Tel: 254-72-129-1615. E-mail: omondivin@yahoo.com
}

Received: July 1, 2014

doi:10.5539/ijef.v6n10p97

\begin{abstract}
The study examined the effects of tax reforms on tax buoyancy and elasticity estimates. The specific objectives of the study were; to determine the effect of tax modernization programme and revenue administration reforms and modernization programme on tax buoyancy and tax elasticity. The study employed regression analysis and used annual time series data for the period 1963 to 2010. Secondary data from Kenya National Bureau of Statistics, Kenya Revenue Authority, Central Bank of Kenya and World Bank was used. Elasticity estimates were determined by adjusting data for discretionary changes using the proportional adjustment method. The study revealed that both revenue administration reform and modernization programme (RARMP) and tax modernization programme (TMP) were important in explaining the variations in buoyancy and elasticity of the tax system in Kenya. Although the reforms analyzed had positive effect on both tax buoyancy and elasticity, the results indicate that this was not sufficient to help generate adequate revenue to finance the ever increasing government expenditure. With an inelastic tax system, the Kenya government has to re-evaluate the implementation strategies and pursue further reforms for it to fully exploit the tax revenue potential in the economy.
\end{abstract}

Keywords: tax reforms, buoyancy, elasticity, gross domestic product

\section{Introduction}

\subsection{Tax Reforms in Kenya}

The Kenya government has been pursuing tax reforms in order to design a system that is viable and productive to finance and sustain government expenditure without recourse to deficit financing. With the devolved structure of governance spelt out in the country's constitution, there has been need for increased revenue collection to sustain the activities for both the devolved and central governments.

Tax reform measures are mainly undertaken in order to restore buoyancy to revenues, strengthen modern taxes, and drastically reduce the complexity and lack of transparency of the system (World Bank, 1990). The main factors contributing to an improved revenue performance are changes in tax legislation, tax administration and minimal tax evasion (Morrisset \& Izquierdo, 1993).

After independence in 1963, Kenya continued to operate under the tax system inherited from the colonial government until early 1970s when policy and administrative changes were initiated. According to KIPPRA (2006), there was little problem with revenue mobilization until 1970s energy crisis necessitated tax reforms to mobilize more revenue. Kenya adopted the income tax act in 1973 (African Development Bank Group, 2010). Since then, there have been three distinct phases of tax reform measures which was the basis of the study.

According to a study by African Development Bank Group (2010), the initial measures were aimed at widening the tax base by way of introducing the sales tax in 1973 and the capital gains tax in 1975. This was a reactive strategy aimed at mitigating against the decline in duty revenues brought about by the imports substitution industrialization policies. The capital gains tax was later abolished in 1984. Parliament just passed a bill seeking to re-introduce the capital gains tax and it is now awaiting assent by the president to make it law.

The major tax reforms began in 1985 following a study by World Bank (1985) which undertook a review of 
Kenya's economic policy that led to a Sessional Paper No. 1 of 1986 (Republic of Kenya, 1986). Therefore, the second phase of tax reforms was Tax Modernisation Programme (TMP) which took place between 1986 and 2002. TMP had the following policy objectives; (i) raise revenue from 22 to 28 percent of GDP, (ii) improve economic efficiency of the tax system through lowering and rationalization of tax rates, (iii) enhance greater reliance on self assessment system supported by selective tax audits, (iv) improve administrative efficiency through computerization, (V) address constraints in existing tax structures as well as overreliance on direct taxes (KIPPRA, 2006).

The formation of Kenya Revenue Authority (KRA) was also articulated in the TMP. KRA was expected to improve tax administration and implement organizational reforms that would improve tax administration (Cheeseman \& Griffiths, 2005). Facing the challenge posed by manual processes, KRA in its second corporate plan recommended a strategy to address this issue in the revenue administration reform and modernisation programme (RARMP) which commenced in 2004/05. This marked the third Phase of tax reforms in Kenya. The goal was to transform KRA into a modern fully integrated and client focused organization (Kenya Revenue Authority, 2003).

Key reforms undertaken under RARMP included; (i) implementation of the Simba system and creation of a Document processing Centre(DPC) in year 2005 which enabled the automation of about ninety per cent of customs operations and dispensed with the need for traders to physically visit KRA. Second reform was the implementation of the customs oil stocks information system (COSIS). COSIS is a web based ICT system that monitors and reconciles oil stocks per oil marketer. Third reform was the introduction of the Electronic Tax Registers (ETR) in year 2005. ETR was aimed at addressing the perennial problem of poor record keeping for business transactions. In year 2008, the Integrated Tax Management System (ITMS) was introduced to facilitate online registration and filing by taxpayers.

The study analysed the three phases of reforms as discussed in order to estimate their effects in improving tax revenue productivity by way of estimating buoyancy and elasticity of the tax system. Each of the phases clearly indicated policy shifts coupled by regime changes; the death of President Kenyatta and President Moi taking over in 1978, NARC government coming into power in 2003 and the coalition government in 2008. Emphasis was on TMP and RARMP reform epochs due to the major shifts the two have brought to the tax system in terms of policy and administration.

\subsection{Statement of the Problem}

Problems of taxation have been receiving special and increasing attention in recent years. In Kenya, because of the limited amount of resources that can be obtained from abroad and from domestic borrowing, the government needs to increase its tax revenues in order to meet social obligations. These demands have pushed the government to continue pursuing its tax reform agenda since taxation is the major source of financing the budget.

Furthermore, with the release of almost 1.9 trillion budget figures in June 2014 (Republic of Kenya, 2014), doubt is being cast on the ability of Kenya Revenue Authority to raise sufficient revenue. The government is also under pressure to finance an expanded government structure spelt out in the current constitution. An understanding of the productivity of the tax system is thus very crucial with the ongoing policy and administrative reforms.

One of the key reasons for undertaking tax reforms has been to create a sustainable tax system that would generate adequate revenue to finance public expenditures. In this respect, the TMP and RARMP reforms undertaken since 1986 endeavor to achieve a tax system that is sustainable in the face of changing conditions domestically and internationally. In spite of the ongoing reforms, tax revenue is falling below targets thus the need to investigate their impact on revenue productivity.

The public expenditures have been increasing and the revenue generation missing targets. The question that arises is, are the tax reforms being carried out effective in tax revenue productivity in Kenya? Therefore, with ongoing tax reforms, it was important to conduct a study to find out its effect on tax buoyancy and elasticity which are measures of tax revenue productivity.

\subsection{Objectives of the Study}

The general objective of the study was to examine the effects of TMP and RARMP reforms on tax revenue productivity in Kenya. The specific objectives of the study were; to determine the effect of tax modernization programme and revenue administration reforms and modernization programme on tax buoyancy and tax elasticity. 


\subsection{Theoretical Literature Review}

The study sought to establish the impact of tax reforms on tax buoyancy hence a review on how to measure tax buoyancy was important. The response of tax revenues to changes in the GDP is measured by tax elasticity and tax buoyancy.

Ole (1975), Wilford and Wilford (1978), Osoro (1993), Ariyo (1997), Wawire (2000), Muriithi and Moyi, (2003), Wawire $(2003,2006)$ estimated tax buoyancy using the following model.

$$
\mathrm{T}=e^{\alpha} Y^{\beta} e^{\varepsilon}
$$

Where; $\mathrm{T}=$ tax revenue, $\mathrm{Y}=$ income (GDP), $\alpha=$ constant term, $\beta=$ buoyancy coefficient and $\mathrm{e}=$ natural number.

Tax elasticity is the product of two components: (1) the base elasticity which is the elasticity of the base with respect to aggregate income; and (2) the rate elasticity which is the elasticity of the tax yield with respect to the base. The change in tax revenues during a given period is the sum total of changes in economic activity and changes due to discretionary tax measures (Trinidad, 1981). The following measurements methods are available:

(a) Proportionate Adjustment Method:

The proportional adjustment (PA) method was originally developed by Prest (1962) and has since been used by Mansfield (1972), Jeetun (1978), Sury (1985), Gillani (1986), Lambert and Suckling (1986), Osoro (1993), and Ariyo (1997). In this method, a series of adjusted tax revenue is first obtained by subtracting from the actual tax revenue in each year the budget estimate of the revenue impact of discretionary changes in that year. The series is further adjusted by excluding the continuing impact of each discretionary change on future year's tax revenue.

The method adjusts a historical revenue series according to a particular year's tax structure on the assumption that this particular tax structure is maintained throughout the period under consideration. Thus, this method basically involves two steps. Firstly, observed revenue data for each year are adjusted for discretionary changes by removing from such data the estimated revenue impact of discretionary changes. This gives an estimate of the automatic growth in revenue between two successive years. Secondly, the series are converted to the first year's basis by adjusting the year to year changes by the ratio of the tax yield on the basis of the first year rates to the actual tax yield (Chelliah \& Chand, 1974).

As argued by Muriithi and Moyi (2003), this method of eliminating the discretionary effects from the revenue series is prevalent in most studies because of it superiority. Wawire (2011) noted that the following model is used for the PA method:

$$
\operatorname{In} T_{p}=\alpha_{p}+\beta_{p} \operatorname{In} Y+\varepsilon_{p}
$$

Where $\beta_{\mathrm{p}}$ provides an estimate of the income elasticity of the $\mathrm{p}^{\text {th }}$ tax; $\mathrm{T}_{\mathrm{p}}$ is $\mathrm{p}^{\text {th }}$ tax, and $\mathrm{Y}$ is income (GDP). Ariyo (1997) suggested additional modifications to the model by suggesting the introduction of a one-year lag in GDP to capture the potential effects on tax revenues due to implementation time lag. This method of estimating tax elasticity suffers from several limitations as highlighted by Ariyo (1997) and Wawire (2011). The first limitation stems from the fact that data on revenue receipts directly and strictly attributable to discretionary changes in tax policy are unavailable. Chipeta (1998) noted that this approach assumes that the discretionary changes are as progressive as the underlying tax structure, hence it is contingent on the assumption that discretionary changes are more or less progressive than the tax structure they modify. This approach is highly aggregative compared to other methods (Wawire, 2011).

(b) Dummy Variable Approach (DVA):

This method involves introduction of a dummy variable for each exogenous tax policy change. The method was developed by Singer (Singer, 1968) and used by Chand and Wolf (1973), Khan (1973) and Artus (1974). Chipeta (1998) argued that although the technique is simple, its usefulness in estimating tax elasticity where the number of discretionary changes is large relative to the length of the data period may be limited.

The dummy variable is used as a proxy for each of the discretionary tax measures (DTMs) to estimate tax elasticity by means of a single equation model of the form:

$$
\operatorname{In} T_{p}=\alpha_{p}+\beta_{p} \operatorname{In} Y+\Sigma \sigma_{i} D_{i}+\varepsilon_{p}
$$

Where the dummy variable $D_{i}(\mathrm{i}=1$, 2.) takes zero $(0)$ before the discretionary change and one (1) after the change. The coefficient $\beta_{p}$ estimates the revenue elasticity. The summation takes care of the possibility of multiple changes during the period covered (Wawire, 2011).

While this technique is simple, its usefulness in estimating tax elasticity where the number of discretionary changes is large relative to the length of the data period may be limited. Ariyo (1997) suggested two additional 
modifications to the model by introducing a one-year lag in GDP to capture the potential effects on tax revenues due to implementation time lag and also introducing a slope dummy variable. The non-dummy and dummy models suggested are:

$$
\begin{gathered}
\operatorname{In} T_{t}=\beta_{0}+\beta_{I} \operatorname{In} Y_{t}+\beta_{2} \ln Y_{t-1} \\
\operatorname{In} T_{t}=\beta_{0}+\beta_{1} \operatorname{In} Y_{t}+\beta_{2} \ln Y_{t-1}+\beta_{3} D_{I}+\beta_{4} D_{2}
\end{gathered}
$$

Where $\mathrm{Y}_{\mathrm{t}-1}=$ previous level of income (GDP), $\mathrm{T}_{\mathrm{t}}=$ total tax revenue, $\mathrm{Y}_{\mathrm{t}}=$ income (GDP), $\mathrm{t}=$ year, $\mathrm{D}_{1}=$ intercept dummy and $\mathrm{D}_{2}=$ slope dummy $\left(\mathrm{D}_{2}=\mathrm{D}_{1} * \mathrm{Y}_{\mathrm{t}}\right)$.

According to Wawire $(2006$; 2011), the major shortcomings of this technique include the fact that it becomes impossible to use the method when tax policy changes are too frequent and that the technique creates a potential multicolinearity problem from the inclusion of more than one dummy variable into the tax function.

(c) Constant Rate Structure Method:

The third approach used in estimating tax elasticity is the Constant Rate Structure Method used by Andersen (1973) for Denmark and Choudhry (1975) for West Malaysia. In this approach, the method is to apply the current year's rates to the previous year's tax bases and to construct the adjusted tax revenue series that would have been obtained, had the same tax structure been applied consistently over time. In order to do this, it is necessary to have a detailed tax-base series for all the individual taxes, which, at times, can be difficult to obtain in most developing countries.

As an example of the level of detailed information required in this particular methodology for revenue forecasting, consider the case of forecasting personal income taxes when the current system has different marginal tax rates for different levels of individual income. In this case, a tax base series with detailed information about the various income brackets is required in order to simulate the current period's marginal tax rate structure over previous years' income brackets and to obtain a clean adjusted series. Similar problems would arise in the case of multiple rates of consumption or excise taxes. However, this method can be used if the number of items is small, the range of tax rates is narrow, and the data can be compiled relatively easily (as in some excise tax cases).

\section{(d) Divisia Index Method:}

Divisia Index is the fourth method. Derived from a weighted sum of growth rate of factor inputs, it is an index of factor inputs, for the measurement of technical change. The index of technical change is the ratio of an index of total productivity to an index of factor productivity; the latter measured by the Divisia index. This measure implies that the percentage increase in total productivity caused by technical progress is equal to the percentage increase in output divided by the percentage increase in factor inputs. The appropriateness of this measure is based on its property of invariance, that is, if there is no technical change, the growth in total productivity is entirely due to factor inputs. A change in the Divisia index, therefore, gives a measure of the change in total productivity that shifts the production function due to all sorts of factors that are jointly termed as technical change (Choudhry, 1979).

\subsection{Empirical Literature}

Ole (1975) estimated income elasticity of tax structure in Kenya for the period 1962/63 to 1972/73. In the study, tax revenue was regressed on income without adjusting for unusual observations. The results showed that the tax structure was income inelastic (0.81) for the period studied. The results also implied that Kenya's tax structure was not buoyant and therefore the country would require foreign assistance to close the budget deficit.

Wawire (1991) assessed the performance of Kenya's tax system from 1958 to 1989 by analyzing the tax capacity factors that were considered to be the main determinants of various tax ratios. Through a regression analysis, the study concluded that increases in the volume of international trade, mining, quarrying, manufacturing, building and construction does increase the tax ratio given by tax/GDP. The result of the study showed an inverse relationship with respect to share of forestry, agriculture and fishing sectors of the economy.

Wang'ombe (1999) analyzed the revenue productivity and some administrative factors of the Kenyan tax system for the period 1989-1998. The result of this study came up with buoyancy estimates of the total tax system as 1.26 while elasticity was 1.27 . The study thus concluded that the tax system in general was both elastic and buoyant implying that tax reforms had greatly improved productivity. Discretionary tax measures had a very small effect on tax productivity implying improved efficiency.

Using total GDP, Wawire (2000) estimated the tax buoyancy and income-elasticity of Kenya's tax system. Tax revenues from various sources were regressed on their tax bases. The study concluded that the tax system had failed to raise necessary revenues. However, the shortcomings of the study were that it never considered other important determinants of tax revenue, for instance the unusual circumstances that could have affected tax 
revenue productivity. It also never disegrated tax revenue data by source hence it was difficult to say which tax bases contributed more to the exchequer. Finally, it never considered the time series properties of the data used.

Muriithi and Moyi (2003) analyzed the productivity of Kenya's tax structure in the context of the tax reforms focusing on pre and post reform period. In the study, they assessed the buoyancy and elasticity of individual taxes and the overall tax system. Their findings suggested that tax reforms had a positive impact on the overall tax structure and on the individual tax handles, even though the impact of the reforms was not always uniform. The reforms had a bigger impact on direct taxes than on indirect taxes, suggesting that revenue leakage is still a major problem for indirect taxes.

Even though the current study adopted model used by Muriithi and Ronge (2003), it differs from their study in some dimension. First, this study used data of since 1963-2010. Second, nominal figures were converted to real figures. Finally this study considered stationarity of a time series data and the data regressed for the whole period of the study.

Wawire (2003) aimed at highlighting the trends in Kenya's tax ratios, tax effort indices and their implication for further tax reforms. In the study tax revenue was regressed on income. The estimated tax equation was used to compute tax effort indices by dividing the predicted with the actual figures. After examining the tax effort indices, the study concluded that the slowdown in economic growth had resulted in high levels of taxation that did not match delivery of public goods and services.

Karingi and Wanjala (2005) evaluated the effect of tax reforms on tax revenue and its composition in the preand post adjustment period, as measured by the tax/GDP ratios and the share of specific taxes in total tax revenue. In their study, they observed that tax yield rose successfully even before the major tax reform programme to peak on average at 19.7 per cent of GDP by the early 1980s. But this level of tax yield compared to the expenditure-to-GDP ratio was nonetheless insufficient. Consequently, they argued that since one of the main objectives of the TMP was to raise tax yield on a zero deficit strategy to match expenditures which were on average 28 per cent of GDP, this objective was never achieved and the best performance in terms of tax yield was during the years 1993/4-97/8, when it climbed to 24.4 per cent of GDP.

Kieleko (2006) evaluated tax revenue productivity in Kenya for the period 1973-2003. The productivity was measured through buoyancy and elasticity. The coefficients were measured through log regression of the taxes to the Gross Domestic Product. The analysis of this study was carried out using the Proportional Adjustment Method (PAM) in capturing the effects of tax reforms on discretionary tax measures and tax productivity. The results showed that there had been a considerable improvement of the tax revenue productivity and that the reforms made in this period had significant effect on the responsiveness of the tax system.

However, this study only concentrated on the TMP reforms and also failed to consider the period immediately after independence when the British tax system was still in force. The current study therefore bridged this gap by analysing the tax system since 1963 and also captured the RARMP reforms which were never captured before.

Wawire (2011) studied the determinants of value added tax revenue in Kenya for the period 1963/64 to $2008 / 2009$. By introducing dummies to cater for unusual behaviours, an OLS regression was done. The study concluded that VAT revenues respond with lags to changes in their respective tax bases implying that the previous levels of tax bases (such as GDP, volume of trade, and volume of imports) have significant influence on the present levels of VAT revenues.

The study further concluded that from the results, it meant that new policy guidelines contained in the budget speeches are not usually implemented immediately hence the long time lag in the response of the taxes influences VAT revenue collected from various sources at a point in time.

\section{Research Methodology}

\subsection{Research Design}

This study aimed at establishing the productivity of the tax system in Kenya hence adopted causal relationship research design. According to Cooper and Schindler (2006), causal analysis is concerned with how one variable affects, or is responsible for changes in another variable. This was important in understanding the relationships between various taxes levied and their proxy bases hence the predictive power of the overall tax system.

\subsection{Model Specification}

Following the works of Ole (1975), Wilford and Wilford (1978a and 1978b), Rao (1979), Omoruyi (1983), Asher (1989), Osoro (1993; 1995), Ariyo (1997), Wawire (2000), Muriithi and Moyi, (2003), Wawire (2003; 2006); the basic estimation procedure for tax buoyancy can be specified in equation (6) in the Cobb-Douglas function of the 
form;

$$
\mathrm{T}=e^{\propto} Y^{\beta} e^{\mu}
$$

Where $\mathrm{T}=$ tax revenue, $\mathrm{Y}=$ income (GDP), $\alpha=$ constant term, $\mathrm{e}=$ natural number, $\beta=$ buoyancy coefficient and $\mu=$ error term

The model used in this study was specified by taking the double logarithm of equation (6) which yields the buoyancy coefficient of $\beta_{k}$ as shown below;

$$
\ln T_{k}=\mathrm{a}_{\mathrm{k}}+\beta_{\mathrm{k}} \operatorname{InY}+\mu_{\mathrm{k}}
$$

Where, $T_{k}=$ revenue from the $k^{\text {th }}$ tax, $\beta_{k}=$ buoyancy coefficient, $a_{k}=$ constant term and $\mu_{k}=$ error term.

To analyse effects of TMP and RARMP reforms, equation (7) was modified by introduction of slope dummy variables taking value 1 for the period with TMP and RARMP reforms and 0 otherwise. The equation estimated for tax buoyancy was;

$$
\ln T_{k}=\mathrm{a}_{\mathrm{k}}+\beta_{\mathrm{k}} \operatorname{In} \mathrm{Y}+\emptyset_{1}\left(D_{1} \ln Y\right)+\emptyset_{2}\left(D_{2} \ln Y\right)+\mu_{\mathrm{k}}
$$

Equation (8) was used to estimate the effects of TMP and RARMP reforms on tax buoyancy thus answering objective (i) and (iii). $\beta_{k}$ gives the magnitude of tax buoyancy during pre reform period while $\emptyset_{1}$ and $\emptyset_{2}$ the magnitude of differential tax buoyancy during post tax reform periods. If $\beta_{k}+\emptyset_{1}+\emptyset_{2}$ is more than $\beta_{k}$, then there will be an upward shift in the degree of tax buoyancy during post tax reform period so long as the coefficients are statistically significant.

With discretionary changes considered, elasticity was estimated by regressing the following equation;

$$
\operatorname{InAT}_{\mathrm{k}}=\alpha_{\mathrm{k}}+\beta_{\mathrm{k}} \text { In Y+ } \mu_{\mathrm{k}}
$$

Where; AT $=$ adjusted revenue from tax $\mathrm{k}, \alpha_{\mathrm{k}}=$ constant, $\beta_{\mathrm{k}}=$ elasticity of the $\mathrm{k}^{\text {th }}$ tax and $\mu_{\mathrm{k}}=$ error term. For tax elasticity estimates, slope dummy variables were introduced in equation (9) as follows;

$$
\ln A T_{k}=\mathrm{a}_{\mathrm{k}}+\beta_{\mathrm{k}} \operatorname{InY}+\emptyset_{1}\left(D_{1} \ln Y\right)+\emptyset_{2}\left(D_{2} \ln Y\right)+\mu_{\mathrm{k}}
$$

Equation (10) answered objective (ii) and (iv). $\beta_{k}$ gave the magnitude of tax elasticity during pre reform period while $\emptyset_{1}$ and $\emptyset_{2}$ the magnitude of differential tax elasticity during post tax reform periods. If $\beta_{k}+\emptyset_{1}+\emptyset_{2}$ is more than $\beta_{k}$, then there is an upward shift in the degree of tax elasticity during post tax reform period so long as the coefficients are statistically significant.

\begin{tabular}{|c|c|}
\hline Variable & Definition and Measurement \\
\hline Tax Revenue (T) & This is the summation of all individual tax revenues measured in Kenya shillings \\
\hline Gross Domestic Product (Y) & $\begin{array}{l}\text { This is the value of goods and services produced in a country over a period of one year regardless of } \\
\text { whether they were produced by foreigners or residents. It will be measured in Kenya shillings. }\end{array}$ \\
\hline TMP (D1) & $\begin{array}{l}\text { This is a slope dummy variable representing the TMP reforms and take value } 1 \text { for the period under TMP } \\
\text { (1986-2002) and } 0 \text { otherwise. }\end{array}$ \\
\hline RARMP (D2) & $\begin{array}{l}\text { This is a slope dummy variable representing the RARMP reforms and take value } 1 \text { for the period under } \\
\text { RARMP (2003-2010) and } 0 \text { otherwise. }\end{array}$ \\
\hline
\end{tabular}

\subsection{Definition and Measurement of Variables}

The variables of the model were; real GDP (Y), total tax revenue (T) and Dummy variables (D) which are the reform variables. Table 1 below shows the variables, their symbols and how they were measured.

Table 1. Table of variables used in the model

\subsection{Data Source, Type and Refinement}

Data from 1963-2010 was obtained from the Kenya National Bureau of Statistics, statistical data from the Kenya Revenue Authority, the Central Bank of Kenya, and World Bank. Both dependent and independent variables were converted from their nominal values to real values. Conversion of time series data for GDP was done by dividing nominal values with the GDP deflator using 1963 as the base year. TMP and RARMP reforms were denoted by slope dummies taking value 1 for the period with TMP and RARMP reforms and 0 otherwise

Real tax revenues were arrived at by dividing the nominal values by the consumer price index (CPI). This was necessary to avoid biased result due to inflation. According to Wawire $(2006,2011)$, CPI is more of a cost of living index hence it is the right to employ for tax revenues which have the effect of reducing disposable income. 


\subsection{Data Analysis and Interpretation}

Before subjecting data to regression analysis, variables were described. This included showing the trends of various variables both in nominal and in real terms. Also the trend of contribution of each tax to revenue was described. This study applied tax revenue model for estimating buoyancy and elasticity. To estimate parameters of the model using Ordinary Least Square method, the equation was linearized by taking the logarithms of the variables in the model.

In adjusting for discretionary changes, proportional adjustment method which was suggested by Prest (1962) and later described by Mansfield (1972) was used. The adjusted data was used to estimate the elasticity. Proportional adjustment method was used because a series of discretionary changes had taken place during the sample period, $1963 / 64$ to $2009 / 10$.

Equation (8) specified was used to examine the effects of TMP and RARMP reforms on tax buoyancy thus answering objective (i) and (iii). $\beta_{k}$ gave the magnitude of tax buoyancy during pre reform period while $\emptyset_{1}$ and $\emptyset_{2}$ the magnitude of differential tax buoyancy during post tax reform periods.

Similarly, Equation (10) was used to answer objective (ii) and (iv). $\beta_{k}$ gave the magnitude of tax elasticity during pre reform period while $\emptyset_{1}$ and $\emptyset_{2}$ the magnitude of differential tax elasticity during post tax reform periods. If the regression coefficients of dummy variables are significantly positive then the average gross tax revenue go up; if significantly negative, then the average gross tax revenue go down during post tax reform periods.

\section{Emperical Results and Interppretation}

\subsection{Stationarity Tests Results}

When time series data is non-stationary and used for analysis it may give spurious results because estimates obtained from such data will possess non constant mean and variance. Because this study used time series data, it was important to establish the Stationarity of the data or what order they are integrated to make sure that the results obtained are not spurious. In this regard Augmented Dickey Fuller (ADF) was used to test for unit roots.

The unit root results of the variables in the model are reported in the appendix; tables 2 and 3 As shown in table 2 , the results of the unit root show that tax was stationary at levels while GDP was stationary after the first difference.

Table 2. ADF unit root at levels

\begin{tabular}{llll}
\hline Variable & ADF statistic & Critical values \\
\hline Total tax revenue & 12.874 & $1 \%$ & -3.578 \\
& & $5 \%$ & -2.925 \\
& & $10 \%$ & -2.601 \\
Gross domestic product & -1.436 & $1 \%$ & -3.578 \\
& & $5 \%$ & -2.925 \\
& & $10 \%$ & -2.601 \\
\hline
\end{tabular}

Table 3. ADF unit root test (After 1st difference)

\begin{tabular}{llll}
\hline Variable & ADF statistic & Critical values & \\
\hline Gross domestic product & 2.128 & $1 \%$ & -2.626 \\
& & $5 \%$ & -1.950 \\
& & $10 \%$ & -1.612 \\
\hline
\end{tabular}

\subsection{Johansen Cointegration Test Results}

Cointegration tests were carried out to verify whether the two variables had a long-run relationship or not. Testing for cointegration required that the residuals for a given regression are integrated of order zero [1(0)] or stationary. If they are stationary [1(0)], although the variables are individually 1(1) or have stochastic trends, their linear combination cancels out the stochastic trends in these variables and as a result, such a regression would be meaningful and not spurious.

Table 4. Cointegration test results 


\begin{tabular}{ccccc}
\hline Eigen value & Likelihood ratio & $5 \%$ critical value & 1\%critical Value & Hypothesized No. of CE(S) \\
\hline 0.229 & 17.601 & 15.41 & 20.04 & None \\
0.115 & 5.625 & 3.76 & 6.65 & At most $1 * *$ \\
\hline
\end{tabular}

Note. $*(*)$ Denotes rejection of the hypothesis at $5 \%(1 \%)$ significance level.

L.R. test indicates 2 co integrating equations at $5 \%$ significance level

From the analysis in table 4, the results indicate two cointegrating equations, given that the likelihood ratio is greater than the critical value at 5 percent significance level and therefore there is a linear combination among the variables. After the cointegration test, the Granger Causality test was conducted.

\subsection{Granger Causality Test Results}

The study sought to find out if there was causation between tax revenue and GDP in Kenya. Granger causality test was carried out to find the causation between the two variables. The results are reported in table 5. The Granger causality test results revealed a bi-directional causality between the tax revenue and GDP.

Table 5. Granger causality test results

\begin{tabular}{ccccc}
\hline Null Hypothesis & F-Statistic & Lags & Probability & Conclusion \\
\hline Tax does not granger cause GDP & $5.735^{*}$ & 4 & 0.001 & \\
GDP does not Granger Cause tax & $3.511^{*}$ & 4 & 0.016 & Bi-directional Causality \\
\hline
\end{tabular}

Note. $*$ Denotes rejection of the null hypothesis at $5 \%$ significance level.

Causality runs in both directions, that is, from tax revenue to GDP and from GDP to tax revenue. There is a two-way causality or a bi-directional causality from tax revenue to GDP and vice versa.

\subsection{Diagnostic Test Results}

The following diagnostic tests were performed on the model to evaluate the validity of the model. They include Jarque-Bera test for normality, LM auto correlation test, ARCH (Auto regressive conditional heteroskedasticity) to detect heteroskedasticity. The results are presented in table 6.

Table 6. LM-test and ARCH test results

\begin{tabular}{ccc}
\hline Test & Obs*R-squared & Probability \\
\hline LM - test & 21.94 & 0 \\
ARCH test & 3.998 & 0.01 \\
\hline
\end{tabular}

From the summarized in table 6, the statistic labeled "Obs*R-squared" is the LM test statistic for the null hypothesis of no serial correlation. The probability value $(0.000)$ indicates absence of serial correlation in the residuals at five percent significance level.

The statistic labeled "Obs*R-squared" is also the ARCH test statistic for the null hypothesis of autoregressive conditional heteroskedasticity $(\mathrm{ARCH})$ in the residuals. The probability value $(0.010)$ indicates that there is no heteroskedasticity in the residuals at five percent significance level.

Under the null hypothesis of a normal distribution, the Jarque-Bera statistic is distributed as $X$ with 2 degrees of freedom. The reported probability is the probability that a statistic Jarque-Bera exceeds (in absolute value) the observed value under the null hypothesis. Thus, a small probability value leads to the rejection of the null hypothesis of a normal distribution. This is shown in the appendix, figure A1. The value Jarque-Bera (299) is greater than that of the given probability $(0.000)$; therefore, the series are normally distributed. This implies that the model has power to capture all the variables.

\subsection{Buoyancy Estimates}

The study sought to estimate the effects of tax reforms on buoyancy of Kenya's tax system. The results are presented in table 7 .

Table 7. Regression results for buoyancy estimates 


\begin{tabular}{llll}
\hline Variable & Coefficient & t-Statistic & Probability \\
\hline Log Gross Domestic Product & $1.144^{*}$ & 42.484 & 0.000 \\
TMP & $0.214^{*}$ & 2.341 & 0.024 \\
Error term(-1) & $-0.283^{*}$ & -3.910 & 0.000 \\
RARMP & $0.455^{*}$ & 3.447 & 0.001 \\
Constant & $-3.322^{*}$ & -12.244 & 0.000 \\
Adjusted R-squared & 0.995 & & \\
F-statistic & 4.491 & & \\
P-value & 0.000 & & \\
\hline
\end{tabular}

Note. * Denotes significance interval at $5 \%$.

Interactive slope dummies were introduced in the regression equation in order to capture the effects of tax reforms on tax buoyancies. From table 3.6, the regression had an adjusted $\mathrm{R}^{2}$ of 0.995 . This means that variations in Gross Domestic Product, revenue administration reform and modernization programme (RARMP) and tax modernization programme (TMP) explain $99.5 \%$ of the variation in the tax revenue in Kenya. The F-value of 4.49 with a probability of 0.00 at $5 \%$ significance level indicates that GDP, RARMP and TMP jointly contribute to the variations in tax revenue.

The coefficient of the error correction term gives the speed of adjustment of each variable towards its long-run equilibrium value. The sign of the coefficient gives the direction of adjustment towards equilibrium. The higher the coefficient of lagged error term, the faster the speed of adjustment towards equilibrium level. If the sign of the coefficient is negative, it implies convergence towards the equilibrium in the long-run.

As indicated in table 7, the coefficient of the error correction term is 0.283 and is significant. It implies a low speed of adjustment. This means that 28 percent of the previous errors in the tax revenue are corrected for in the current period. The following is a discussion of each variable with regard to sign, significance and possible policy implications.

The coefficient of $\log$ GDP was statistically significant as shown by a t-ratio of 42.48 . The coefficient of this variable is positive suggesting that if GDP increases by $1 \%$ total tax revenue increases by $1.144 \%$. This means that the tax system yielded a $1.144 \%$ change in tax revenue as a result of changes in discretionary policy measures for every $1 \%$ change in GDP.

The implication of the buoyancy coefficient greater than unity is that discretionary changes were important in raising tax revenue. The results confirm the causality results that indicate a bi-directional causation between tax collected and GDP. These results are consistent with the findings of Njoroge (1993), Wang'ombe (1999), Moyi and Muriithi (2003) who found a buoyancy coefficient of more than unity.

The study employed the use of two dummy variables to represent the reforms which have been implemented by the government to enhance the revenue collection. The regression results indicate that both revenue administration reforms and modernization programme and tax modernization programme were statistically significant. Since they were represented by the use of the dummy variables, the coefficients of the variables could not be interpreted as buoyancies.

The dummy coefficients measured the discontinuous effect of the changes in income and tax policy decisions. This captured the interaction effect of tax reforms on gross tax revenue.

Revenue Administration Reform and Modernization Programme (RARMP) had a t-statistic of 3.447 and a P-value of 0.000 . This implies that the revenue administration reforms had a positive impact on the overall tax structure. The positive impact of the programme could be associated with the organizational re-alignment achieved by the implementation of the various tax reforms.

During the period of RARMP reforms, the differential buoyancy estimate was found to be 0.455 . It therefore implies that the reforms improved tax buoyancy by about $46 \%$ over the reform period thereby a boost in revenue collection. This positive impact can be attributed to objectives set by KRA through a number of initiatives which included: broadening of tax base and widening the tax net; improving voluntary compliance; enhancing and improving assessments/audits; improving debt/arrears and exemptions management; and implementation of an integrated enforcement policy.

Tax Modernization Programme (TMP) had a t-statistic of 3.447 and a P-value of 0.000 . This implies that the revenue administration reforms had a positive impact on the overall tax structure. The primary aim of the TMP 
was to raise the revenue-to-GDP ratio from $22 \%$ in 1986 to $24 \%$ by the mid-1990s, although this target was increased to 28\% in 1992. The Tax Modernization Programmes reforms were aimed at encouraging a free market atmosphere and therefore increasing the level of foreign direct investment.

The results indicate that differential tax buoyancy estimate under TMP reforms was 0.214 implying $21 \%$ increase in tax revenue collection over the period. This is a slight improvement in buoyancy of the tax system. Although there was an upward shift in revenue collection for both categories of reforms, RARMP had a higher effect on tax buoyancy as compared to TMP reforms. Doing away with some of the manual processes could have led to this difference since RARMP enhanced computerization, online declarations and clearance of goods. That in effect limited interaction between tax officers and taxpayers hence reducing revenue leakages as a result of corruption.

\subsection{Estimation for Elasticities}

The second and fourth objectives of the study aimed at determining the effect of TMP and RARMP on elasticity of the Kenya's tax system. In order to address these objectives, data was adjusted for discretionary changes. A regression analysis was carried out and the results shown in table 8.

Table 8. Regression results for elasticity estimates

\begin{tabular}{llll}
\hline Variable & Coefficient & t-Statistic & Probability. \\
\hline Log Gross Domestic Product & $0.690^{*}$ & 8.825 & 0 \\
Error term (-1) & $0.775^{*}$ & 8.787 & 0 \\
TMP & $0.554^{*}$ & 4.301 & 0 \\
RARMP & $0.199^{*}$ & 2.361 & 0.034 \\
Constant & $-2.505^{*}$ & -27.215 & 0 \\
Adjusted R-squared & 0.998 & & \\
\hline
\end{tabular}

Note. * Denotes that the coefficient is significant at $5 \%$ level.

The results, presented in Table 8 indicate that the elasticity for Kenya's overall tax system is 0.690 . This implies that the increase in national income spurred a less than proportionate increase in tax revenue. The results are consistent with the findings of Njoroge (1993), Moyi and Muriithi (2003) and Wawire (2006) who found the overall tax system to be inelastic. Results however deviate from the findings of Wang'ombe (1999) who found an elasticity coefficient of 1.27 .

The coefficient of error correction term gives the speed of adjustment of each variable towards its long-run equilibrium value, while the sign of the coefficient gives the direction of adjustment towards equilibrium. From the results, the coefficient of the error correction term is 0.775 and is significant. It implies a high speed of adjustment. This means that 77 percent of the previous errors in the tax revenue are corrected for in the current period.

The results from the regression indicate that the tax modernization progrmme (TMP) and revenue administration reform and modernization programme (RARMP) increased the revenue collected over the reform period. This is indicated by the t-ratios of the coefficients of these reform programmes. The results are in line with the findings of Kieleko (2006) who found TMP reforms to have a positive impact on Kenya's tax system.

The differential elasticity coefficients were 0.554 and 0.199 for TMP and RARMP respectively. It is therefore apparent that the elasticity ratio increased by 55.4\% during TMP reforms and $19.9 \%$ during RARMP reforms. TMP seem to have had a bigger impact. It is therefore clear that these reforms appear to have improved tax elasticity more than the buoyancy. This is expected since reforms ought to improve automatic response of the tax system to changes in GDP rather than the responsiveness of the tax system to discretionary policy measures undertaken by the government.

\section{Summary, Conclusion and Policy Implications}

\subsection{Summary}

The findings suggest that tax reforms had a positive impact on the overall tax structure as illustrated by the coefficients of slope dummies. Since buoyancy and elasticity are measures of tax revenue productivity; the positive effects as established on the two as a result tax reforms, implies an improvement in revenue generation capacity of Kenya's tax system. 
The first objective of the study was to determine the effect of tax modernization programme on tax buoyancy in Kenya. The results indicated that the buoyancy coefficient was greater than unity. That is, 1.144 and 1.358 for pre and post reform periods respectively. This implies that discretionary changes were important in raising revenue. Furthermore, tax modernization reforms improved the buoyancy coefficient over the study period.

The second objective was to investigate the effect of tax modernization programme on tax elasticity in Kenya. The regression results indicate an inelastic tax system with an elasticity coefficient of 0.690 during the pre reform period. However, with the implementation of tax modernization programme reforms, the elasticity coefficient improved by 0.554 .

The third and fourth objectives were to determine the effect of revenue administration reforms and modernization programme on tax buoyancy in Kenya and to investigate the effect of revenue administration reforms and modernization programme on tax elasticity in Kenya respectively. The reforms were included in the regression models as dummies for estimation purposes. The study showed that the revenue administration reform and modernization programme (RARMP) and tax modernization programme (TMP) were important in explaining the variations in the buoyancy of tax system in Kenya and also on the elasticity of the tax system.

Although the reforms analyzed had positive effect on both tax buoyancy and elasticity, the results indicate that this was not sufficient to help generate adequate revenue to finance the ever increasing government expenditure. With an inelastic tax system, the Kenya government has to re-evaluate the implementation strategies and pursue further reforms for it to fully exploit the tax revenue potential of the economy.

\subsection{Conclusion}

In conclusion, the study revealed that Kenya has a buoyant tax system. This implies that budgetary changes have increased the responsiveness of tax revenues to income changes. It was found that discretionary tax measures have had an overall impact on growth in total revenue over the period. However, the automatic response of revenue to changes in the tax base was found to be less than unity.

The study further revealed that Kenya has an inelastic tax structure. Taxes are not greatly responsive to changes in income with the elasticity coefficient registering below unity. The low elasticity observed in the Kenya's tax system is explained through factors such as exemptions, tax incentives, duty waivers, low compliance and vibrant sectors of the economy which are not subject to taxation. Therefore, the automatic responsiveness of taxes to income is seen to be low.

Although reforms undertaken improved tax elasticity, it was not sufficient in generating adequate revenue required to finance the budgets. This implies that the ability of the economy to increase revenue on its own remains fairly weak requiring discretionary measures coupled with increased borrowing to make up for the shortfalls in revenue. This leads to the conclusion that, discretionary tax measures impact favorably on total tax revenue. It can therefore be deduced that a big percentage of tax revenue comes from discretionary tax policy and not from pure responsiveness of tax revenue to changes in national income.

\subsection{Policy Implications}

In order to stimulate higher economic growth, a well-designed tax system should be put in place to encourage competitive growth across various sectors of the economy. Even more importantly, the distortion and/or opportunities created by a tax system should not be the cause for tax planning, but provide direction towards more productive endeavors through lowering the tax rates, eliminating tax on tax and widening the base. Secondly the government should reduce tax rates further especially for taxes on capital and intermediate goods so as to encourage more investments and promote business activities. These measures will help improve further on the tax buoyancy thereby ensuring that the tax system generates a sustainable revenue capacity.

The government needs to facilitate the growth of domestic manufactured output and widen tax bases. This is because the less than unity tax elasticity could be attributed to a narrow tax base. Generally, the total tax revenue of the government will invariably depend upon the size of the tax base, the levels of tax rates adopted within the tax system, administrative efficiency, and the compliance rate. The taxes introduced should be appropriate and sufficient to finance the expenditure needs of the government over time. In other words, revenues should rise with national income, and the entire tax system should evolve to enhance the revenue yield over time.

An effective tax administration is needed to improve tax compliance, enhance revenue collection and to prevent tax evasion. RARMP reforms improved tax elasticity by 0.199 . This effect is marginal. The problem could therefore be due to implementation mechanisms put in place by KRA. To harmonize the operations of revenue agencies, there is need to increase resource allocation to Kenya Revenue Authority. This will enable it be more effective in pursuing tax reforms. 
Furthermore, KRA should pay more attention to taxpayer education, compliance and tax audits. This is because despite tax reforms, the tax system remains inelastic post TMP and RARMP reforms. These measures will enhance tax revenue collection as a result of taxpayers embracing the reforms undertaken and also understanding their tax obligations. With complex tax laws, taxpayers have to bear additional costs in order to interpret the law and process tax returns. This tends to give the taxpayers an incentive to evade tax and, therefore, provides a rationale for aggressive taxpayer education.

\section{References}

Adari, M. M. (1997). Value Added Tax in Kenya. Unpublished M.A. Research Paper, University of Nairobi.

African Development Bank Group. (2010). Domestic resource mobilization for poverty reduction in East Africa: Kenya case study.

Andersen, S. P. (1973). Built-in flexibility of sensitivity of the personal income tax in Denmark. Swedish Journal of Economics, 75, 23-38. http://dx.doi.org/10.2307/3439271

Ariyo, A. (1997). Productivity of the Nigerian tax system: 1970-1990. Research paper No. 67. Nairobi: African Economic Research Consortium.

Artus, K. K. (1974). Tax revenue forecasting: A Methodological study with application to Turkey. Studies in Domestic Finance, 5.

Chand, S. K., \& B. Wolf. (1973). The Elasticity and Buoyancy of the Tax System of Peru, 1960-1971: An Empirical Analysis. Unpublished Paper, IMF.

Cheeseman, N., \& Griffiths, R. (2005). Increasing tax tevenue in Sub-Saharan Africa: The case of Kenya. Oxford Council on Good Governance Economic Analysis No. 6. United Kingdom: Oxford.

Chelliah, R. J., \& Sheetal, C. K. (1974). A Note on Techniques of Adjusting Tax Revenue Series for Discretionary Changes. Unpublished Paper, IMF.

Chipeta, C. (1998). Tax reform and tax yield in Malawi. AERC Research Paper No. 81. Nairobi: AERC.

Choudhry, N. N. (1979). Measuring the elasticity of tax revenue: A divisia index approach. IMF Staff Paper, 26, 87-96. http://dx.doi.org/10.2307/3866566

Cooper, D. R., \& Pamela, P. S. (2006). Business research methods (9th ed.). New Delhi: Tata McGraw-Hill publishing company.

Deaton, A. (1988). Econometric issues for tax design in developing countries. In D. Newbery \& N. Stem (Eds.), The theory of taxation for developing countries (pp. 92-113). Washington, D.C: The World Bank.

Di John, J. (2009). Conceptualizing the causes and consequences of failed state: A Critical Review of the Literature. Crisis States Working Paper, 2, 25.

Dickey, D. A., \& Fuler, W. A. (1981). Likelihood ratio statistics for auto regressive time series with a unit root. Econometrica, 49, 1057-1072. http://dx.doi.org/10.2307/1912517

Dickey, D. A., \& Fuller, W. A. (1979). Distribution of the estimators for autoregressive time Series with a unit root. Journal of the American Statistical Association, 74, 427-431. http://dx.doi.org/10.2307/2286348

Gillani, P. S. (1986). Elasticity and bouyancy of federal taxes in Pakistan. The Pakistan Development Review, 25(2), 163-174.

Goode, R. (1984). Government finance in developing countries. New Delhi: Tata Mc Graw Hill publishing Co. Ltd.

Gujarati, D. N. (1995). Basic Econometrics. New York: McGraw Hill Book Companies, Inc.

Jeetun, A. (1978). Bouyancy and elasticity of taxes in Pakistan. Applied Economics Research Institute: Research Paper, No.11.

Karingi, S. N., \& Wanjala, B. (2005). Tax reforms experience of Kenya. Research Paper No. 2005/67. Worldwide Institute of Development Economics Research. United Nations University.

Kenya Revenue Authority. (2003). Second corporate plan, 2003/04-2005/06. Nairobi: KRA.

Kenya Revenue Authority. (2006). Third corporate plan, 2006/07-2008/09. Nairobi: KRA.

Kenya Revenue Authority. (2010). Revenue administration in Kenya: Experience and lessons. Nairobi: KRA.

Khan, M. Z. (1973). Responsiveness of tax yields to increase in national income. Pakistan Development Review, 
$11,22-39$.

Kieleko, P. M. (2006). The effects of tax reforms on tax productivity in Kenya. Unpublished M. A Project. University of Nairobi.

KIPPRA. (2001). Revenue design: The Kenyan experience. Tax policy unit, macroeconomics division. Nairobi: Kenya Institute of Public Policy Research and Analysis.

KIPPRA. (2004a). Tax compliance study. Tax policy unit, macroeconomics division. Nairobi: Kenya Institute of Public Policy Research and Analysis.

KIPPRA. (2004b). Tax reforms experience and the reform agenda for Kenya. Policy Brief No. 3. Nairobi: Kenya Institute of Public Policy Research and Analysis.

KIPPRA. (2006). Lessons from Kenya's tax reforms experience. Policy Brief No. 10, Nairobi: Kenya Institute of Public Policy Research and Analysis.

Lambert, J. D., \& Suckling, R. J. (1986). Revenue elasticity of the Zimbabwean individual income tax, 19671981. Zimbabwe Journal of Economics, 1, 1-9.

Leuthold, J. H. (1991). Tax shares in developing countries: A panel study. Journal of Economics, 35, $173-185$.

Leuthold, J. H., \& Guessan, T. N. (1986). Tax bouyancy and elasticity in developing economy. Bureau of Economic and Business Research, Faculty Working Paper No. 1272; University of Illinois, Urban Campaign.

Mankiw, N. G., Weinzierl, M., \& Yagan, D. (1993). A symposium on Keynesian economics today. Journal of Economic Perspectives, 7, 3-82. http://dx.doi.org/10.1257/jep.7.1.3

Mankiw, N. G., Weinzierl, M., \& Yagan, D. (2010). Optimal taxation in theory and practice. Journal of Economic Perspectives, American Economic Association, 23(4), 147-74. http://dx.doi.org/10.1257/jep.23.4.147

Mansfield, C. Y. (1972). Elasticity and Buoyancy of a tax system: A method applied in Paraguay. IMF Staff Papers, 19.

Mayshar, J. (1990). On Measures of Excess Burden and their Applications. Journal of Public Economics, 43(3), 263-289. http://dx.doi.org/10.1016/0047-2727(90)90001-X

McLure, C. E. Jr. (1989). The Taxation of Income from Business and Capital in Colombia. Durham, N.C: Duke University Press.

Morrisset, J., \& Izquierdo, A. (1993). Effects of tax reform on Argentina's revenues. WPS 1192. Washington, D.C: The World Bank.

Moyi, E., \& Ronge, E. (2006). Taxation and tax modernization in Kenya: a diagnosis of performance and options for further reform. Institute of Economic Affairs, December.

Muriithi, M. K., \& Moyi, E. D. (2003). Tax reforms and revenue mobilization in Kenya. AERC Research Paper 131, Nairobi: AERC.

Musgrave, R. (1987). Tax reform in developing countries. In D. Newberry \& N. Stern (Eds.), The theory of taxation for developing countries (pp. 242-263). Oxford: Oxford University Press.

Nellor, D. C. L. (1995). Taxation of Mineral and Petroleum Resources (p. 238). Washington, D.C: International Monetary Fund.

Newbery, D. (1988). Taxation and development. In D. Newbery \& N. Stem (Eds.), The theory of taxation for developing countries (pp. 165-204). Washington, D.C.: The World Bank.

Njoroge, J. W. (1993). Revenue productivity of tax reforms in Kenya: 1972/73-1991/92. Unpublished M.A. Research paper: University of Nairobi.

Ole, A. M. (1975). Income elasticity of tax structure in Kenya: 1962-1973 unpublished. MA Research Paper, University of Nairobi.

Osoro, N. E. (1993). Revenue productivity implications of tax reform in Tanzania. Research Paper No. 20, Nairobi; African Economic Research Consortium.

Prest, A. R. (1962). The sensitivity of yield of personal income tax in United Kingdom. Economic Journal, 52, 576-596. http://dx.doi.org/10.2307/2228439 
Ramsey, F. B. (1927). A contribution to the theory of taxation. Economic Journal, 37(1), 47-61. http://dx.doi.org/10.2307/2222721

Republic of Kenya. (1986). Sessional Paper No. 1 of 1986 on economic management for renewed growth. Nairobi: Government printer.

Republic of Kenya. (2003). Economic recovery strategy for wealth and employment creation (2003-2007). Nairobi: Government printer.

Republic of Kenya. (2014). Kenya Government Budget Statement (2014/2015). Nairobi: Government printer.

Republic of Kenya. Statistical Abstracts, Various issues. Nairobi: Government printer.

Singer, N. M. (1968). The use dummy variable in establishing the income elasticity of state income tax revenue. National Tax Journal, 21, 200-204.

Slemrod, J. (1990). Optimal taxation and optimal tax systems. Journal of economic Perspectives, 4(1), 157-78. http://dx.doi.org/10.1257/jep.4.1.157

Slemrod, J. (1996). Which is the simplest tax system of them all? In J. A. Henry \& G. G. William (Eds.), Economic effects of fundamental tax reform (pp. 335-391). Washington D.C.: The Brookings Institution.

Stern, N. H. (1988). The theory of optimal commodity and income taxation: An introduction. In D. Newbery \& N. Stein (Eds.), The theory of taxation for developing countries (pp. 22-59). Washington, D.C: The World Bank.

Sury, M. M. (1985). Bouyancy and elasticity of union excise tax revenues in India: 1950-1951 to 1980-1981. National Council of Applied Economic Research, 18.

Tanzi, V., \& Zee, H. H. (2000). Tax policy for emerging markets: Developing countries. National Tax Journal, 53(2), 299-322.

Thirsk, W. (1995). Lessons from tax reforms: An Overview. In J. Khalilzadeh-Shirazi and A. Sha (Eds.), Tax policy in developing countries. Washington, D.C.: The World Bank.

Wagacha, M. (1999). Fiscal policies and their macroeconomic implications for Kenya. In P. Kimuyu, W. Mbui, \& A. Okwach (Eds.). Kenya's strategic policies for the 21st Century: Macroeconomic and sectoral choices. Nairobi: Institute of Policy Analysis and Research Population.

Wang'ombe. (1999). An analysis of the revenue productivity and some administrative factors of the Kenyan tax system. University of Nairobi, M.A Thesis, unpublished.

Wawire, N. H. W. (1991). An empirical assessment of tax performance in Kenya: 1958-1989. M. A. Research Paper, Kenyatta University.

Wawire, N. H. W. (2000). Revenue productivity implications of Kenya's tax system. In K. Kwaa Prah, \& A. G. M. Ahmed (Eds.), Africa in transformation. Political and economic issues (Vol. 1, pp. 99-106). Addis Ababa: OSREA.

Wawire, N. H. W. (2003). Trends in Kenya's tax ratios and tax effort indices, and their implication for future tax reforms. Egerton Journal, 4, 256-279.

Wawire, N. H. W. (2006). Determinants of tax revenues in Kenya. Unpublished Ph.D Thesis, Kenyatta University.

Wawire, N. H. W. (2011). Determinants of value added tax revenue in Kenya. The CSAE Conference Paper, March, St Catherine's College.

Wilford, S. D., \& Wilford, W. T. (1978a). Estimates of revenue elasticity and buoyancy in Central America: 1955-1974. In J. F. J. Toye (Ed.), Taxation and economic development (pp. 83-100). London: Frank Cass \& Co. Ltd.

World Bank. (1985). Ghana: Towards Structural Adjustment. Washington, D.C: The World Bank.

World Bank. (1990). Argentina: Tax policy for stabilization and economic recovery. Country Study. Washington, D.C.: The World Bank. 


\section{Appendix A}

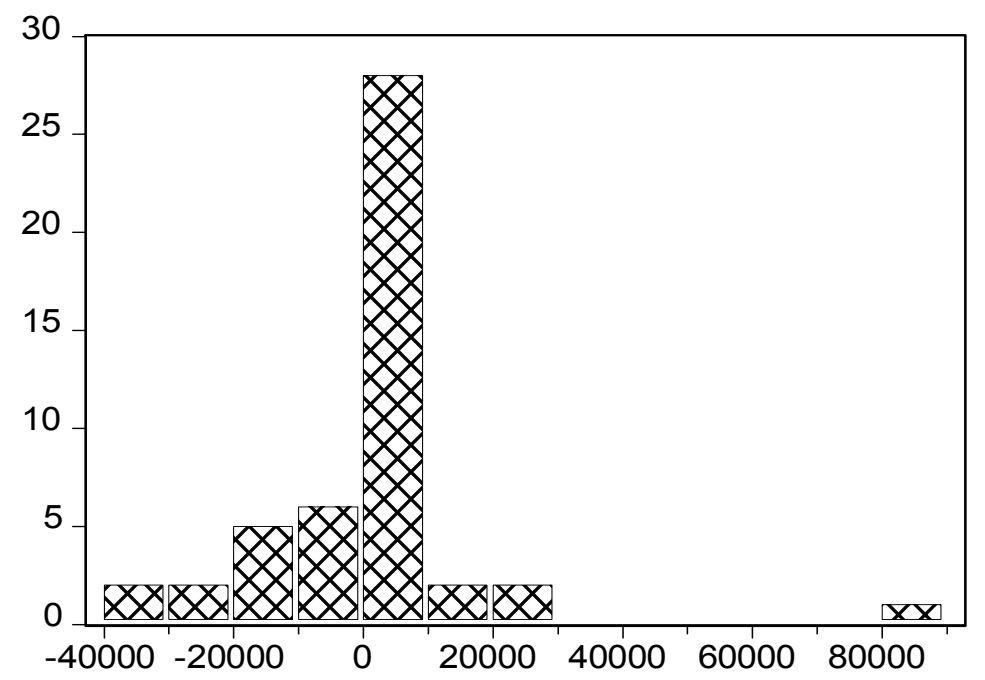

Series: Residuals Sample 19632010

Observations 48

Mean

$-2.43 \mathrm{E}-12$

Median

767.8724

Maximum

86719.19

Minimum

$-31324.22$

Std.Dev.

17416.99

Skewness

2.241445

Kurtosis

14.38104

Jarque-Bera $\quad 299.2486$

Probability

0.000000

Figure A1. Normality test results

\section{Copyrights}

Copyright for this article is retained by the author(s), with first publication rights granted to the journal.

This is an open-access article distributed under the terms and conditions of the Creative Commons Attribution license (http://creativecommons.org/licenses/by/3.0/). 